Zeszyty Naukowe Rozprawy Humanistyczne

$1(1) / 2016$

ISSN: 1731-2221

DOI: http://dx.doi.org/10.21784/RH.2016.003

Bartosz Nieścior

Uniwersytet Warszawski

\title{
Polityka gospodarcza Niemiec w latach 1924-1929 - wybrane zagadnienia
}

\author{
German economic policy in the years 1924-1929 - selected isues
}

\section{Streszczenie:}

W artykule została przedstawiona problematyka polityki gospodarczej Niemiec w latach 1924-1929. Stworzenie nowego państwa niemieckiego - jakim była Republika Weimarska było niewątpliwie próbą utworzenia odmiennego ładu demokratycznego, z liberalnym podejściem do gospodarki.

Sytuacja gospodarcza i ekonomiczna młodej republiki rozwijała się bardzo szybko. Państwo niemieckie zmagało się z licznymi manifestacjami, próbami zamachu stanu, jak również było zmuszone do płacenia reparacji wojennych. W latach 1924-1929 Rzesza Niemiecka przeżywała największy wzrost gospodarczy i ekonomiczny, głównie ze względu na napływ dużej ilości kapitału zagranicznego. Późniejszy zwrot ku nacjonalizmowi i przejęcie władzy przez Adolfa Hitlera doprowadziło do upadku Republiki Weimarskiej, a co za tym idzie destabilizacji ekonomicznej i politycznej kraju.

Jednak należy zauważyć, iż gospodarka Rzeszy Niemieckiej, pomimo wielu problemów została odbudowana, a państwo niemieckie dzięki temu odzyskało swoją pozycję w Europie - sprzed okresu I wojny światowej. Niestety zdarzenia, które miały miejsce później całkowicie pozbawiły jakichkolwiek nadziei na rozwój i prowadzenie polityki gospodarczej w oparciu o wolność, poszanowanie własności, czy pomoc publiczną.

\footnotetext{
Abstract:

This article presents issues of German economic policy in the years 1924-1929. The creation of a new German state - which was the Weimar Republic was undoubtedly an attempt to create a different democratic order, with a liberał approach to the economy.

The economic situation and economic young republic developed very ąuickly. German state struggled with numerous manifestations, coup attempts, and was forced to pay war reparations. In the years 1924-1929 the German Reich experienced the greatest growth and economic, mainly due to the influx of large amounts of foreign capital. Later turn towards nationalism and the seizure of power by Adolf Hitler led to the collapse of the Weimar Republic, and hence economic and political destabilization of the country.

However, it should be noted that the economy of the German Reich, in spite of many problems was rebuilt, and the German state thus regained its position in Europę - pre-First World War. Unfortunately, the events that took place later completely deprived of any hope of development and economic policies based on freedom, respect for property, or public assistance.
} 


\section{Słowa kluczowe:}

Republika Weimarska, polityka gospodarcza Republiki Weimarskiej, sytuacja gospodarcza w Niemczech 1924-1929, plan naprawy gospodarki Rzeszy Niemieckiej, reparacje wojenne

\section{Keywords:}

the Weimar Republic, the economic policy of the Weimar Republic, the economic situation in Germany 1924-1919, the plan for recovery of the German Reich, war reparation

\section{Wprowadzenie}

Powstanie demokratycznej republiki, z parlamentarnym systemem rządów, było zupełnym przeciwieństwem ustroju, który obowiązywał w Cesarstwie Niemieckim. Republika Weimarska, można stwierdzić, iż była drugą, lepszą próbą stworzenia nowego porządku prawnoorganizacyjnego państwa, po tej, która miała miejsce w czasie rewolucji marcowej w roku 1848.

Historia nowo powstałej Rzeszy Niemieckiej była bardzo burzliwa. Można ją podzielić na trzy główne okresy:

1.lata kryzysu 1919-1923 (m.in., próby dokonania zamachu stanu, hiperinflacja);

2.stabilizacja polityczna i rozwój gospodarczy - 1924-1929;

3.zmierzch i upadek republiki 1930-1933 (zwrot ku nacjonalizmowi, przejęcie władzy przez narodowo-socjalistyczną partię Adolfa Hitlera NSDAP).

Sytuacja gospodarcza i ekonomiczna państwa niemieckiego zmieniała się dynamicznie. Upadek republiki spowodowały m.in. działania wojenne, prowadzone podczas I Wojny Światowej przez Niemcy. Szkody, które zostały spowodowane przez państwo niemieckie, na rzecz innych krajów europejskich, były odczuwalne praktycznie do czasu przejęcia władzy przez Hitlera - to w dużym stopniu one spowodowały upadek polityki gospodarczej w Rzeszy Niemieckiej. Kwoty reparacji wojennych, były liczone w miliardach złotych marek, Niemcy nie były w stanie spłacić tak dużego zadłużenia. Władze niemieckie, zmuszone były zapożyczyć się u państw zachodnich i Stanów Zjednoczonych. Wszystkie te czynniki, przyjmujące postać rozruchów na tle politycznym, brak równowagi gospodarczej, odszkodowania wojenne i na koniec przejęcie władzy przez skrajnych nacjonalistów -uniemożliwiały zachowanie stabilności finansowej Republiki Weimarskiej. Były również blokadą w prowadzeniu polityki, która ma na celu rozwój ekonomiczno-gospodarczy państwa oraz podtrzymanie stabilności ustrojowej.

Głównym zamysłem artykułu, było opisanie najważniejszych - wybranych zagadnień związanych z polityką gospodarczą państwa niemieckiego (1924-1929), oddających ówczesną sytuację ekonomiczno-polityczną wewnątrz państwa niemieckiego i na arenie międzynarodowej.

Zgodnie z powyższym, w przedstawionym artykule, najpierw opisano i przedstawiono najważniejsze zagadnienia państwowości oraz ustroju Republiki Weimarskiej, wraz nakreśleniem zarysu polityki gospodarczej państwa. Następnie, poddano analizie plany gospodarcze Dawesa i Younga, a także problem reparacji wojennych oraz sytuacji gospodarczej państwa niemieckiego $\mathrm{w}$ latach 1924-1929. W ostatnim punkcie, dokonano podsumowania i przedstawienia oceny przeprowadzonych reform gospodarczych państwa niemieckiego we wskazanym okresie.

Podczas opracowywania artykułu zastosowano hermeneutyczną i analityczną metodę badawczą. 


\section{Ustrój Republiki Weimarskiej - zagadnienia ogólne}

Analiza reform gospodarczych państwa niemieckiego w latach 1924-1929, nie byłaby możliwa bez przedstawiania genezy powstania nowego tworu - jakim była Republika Weimarska wraz z opisem jej ustroju.

W dniu 31 lipca 1919 r. Zgromadzenie Narodowe głosami koalicji weimarskiej, która składała się z socjaldemokratów, demokratów i katolickiego Centrum, a przeciw głosom nacjonalistyczno-konserwatywnych (deutschnationale), prawicowo-liberalnej (Yolkspartei) i lewicowego odłamu socjalistów związanych z niezależnymi uchwaliło konstytucję weimarską1. Początkowo nastroje demokratyczne przedstawiali jedynie socjaldemokraci, następnie dołączyli do nich liberalni lewicowcy oraz katolickie Centrum ${ }^{2}$. Osoby o poglądach prawicowych były w opozycji wobec nowego ustroju. Skrajna lewica, co jest interesujące -była gotowa walczyć o republikę, lecz nie o parlamentarno-demokratyczną, ale radziecką3.

W nowo powstałym demokratycznym ustroju Niemiec suwerenem był naród niemiecki zgodnie z art. 1 Konstytucji Weimarskiej4 - który wybierał skład parlamentu niemieckiego Reichstagu oraz Prezydenta Rzeszy. Wprowadzono po raz pierwszy trójpodział władzy. Rząd ponosił odpowiedzialność przed parlamentem. Prezydent każdorazowo, w przypadku podjęcia jakiejkolwiek decyzji, potrzebował zgody kanclerza lub jednego z ministrów 5. Podział administracyjno-prawny Rzeszy uległ licznym modyfikacjom. Między innymi, istotną różnicą było zastąpienie dotychczasowej nazwy państw związkowych (Bundesstaateń) i wprowadzenie tzw. krajów związkowymi (Lander) - którym pozostawiono w swoich kompetencjach praktycznie całą politykę wewnętrzną wraz z policją ${ }^{6}$ Można powiedzieć, że konstytucja nadała państwu niemieckiemu charakter federacji. Landy miały swoje sejmiki, organa, sądy czy nawet konstytucję. Mogły także prowadzić własną politykę wewnętrzną. Pozostawienie tak dużej autonomii i swobody w poszczególnych krajach Rzeszy, m.in. w kształtowaniu swojego ustroju wewnętrznego, zapewne miało charakter pewnego novum w dotychczasowej historii Niemiec. Rada Rzeszy, która istniała jeszcze w czasach Cesarstwa Niemieckiego, miała również rację bytu w czasach Republiki Weimarskiej. Był to organ przedstawicielski, w którym zasiadali przedstawiciele poszczególnych landów. Każdy z nich miał prawo do głosowania. Co ciekawe, instytucja ta, nie posiadała prawa inicjatywy ustawodawczej, lecz mogły być do niej składane poszczególne projekty ustaw przez rządy krajowe. Należy pamiętać, iż każdy kraj (Land) miał swoją konstytucję związkową, którą sam uchwalał zgodnie z duchem demokracji. Wszystkie sprawy wykonywane przez organy krajowe musiały być w zgodzie z konstytucją krajową7.

Wydawałoby się więc, iż nowo powstały ustrój o stabilnym podłożu demokratycznym, w postaci m.in. powyżej opisanych aspektów prawnych, oraz poszczególnych instytucji publicznych - śmiało będzie się rozwijać i polepszać sytuację gospodarczą. Ustrój Republiki Weimarskiej oparty w dużej mierzy na aparacie państwowym wilhelmowskiej Rzeszy miał być swego rodzaju mechanizmem do rozszerzania procesu demokratyzacji i zrywania z historią despotycznego charakteru Cesarstwa Niemieckiego.

\footnotetext{
${ }^{1}$ J. Krasuski, Historia Rzeszy Niemieckiej 1871-1945, Wydawnictwo Poznańskie 1969, s. 238.

${ }^{2}$ T. Kotłowski, Historia Republiki Weimarskiej 1919-1933, Instytut Historii UAM, Poznań 1997, s. 35.

${ }^{3}$ Ibidem.

${ }^{4}$ Die Yerfassung der Weimar er Republik v om 11., August 1919, Stuttgart 2009, s. 3.

${ }^{5}$ J. Krasuski, Historia Rzeszy Niemieckiej 1871-1945, op. cit., s. 238.

${ }^{6}$ Ibidem.

${ }^{7}$ Die Yerfassung der Weimarer Republik vom ii., August 1919, Stuttgart 2009, s. 4.
} 
Europa w latach 1924 - 1929 r. przeżywała okres rozkwitu gospodarczego. Było to spowodowane m.in. pragnieniem szybkiej likwidacji skutków wojny przez państwa europejskie, a także chęcią regulacji sporów międzynarodowych na drodze rokowań i rozjemstwa ${ }^{8}$. Warte zauważenia jest, iż Niemcy w powyżej wskazanym okresie mogli pochwalić się szybszym wzrostem gospodarczym niż sama Wielka Brytania. Można powiedzieć, iż kryzys ustrojowy, społeczny i gospodarczy, dotykających większości osób w państwie niemieckim, powstał na skutek informacji o ogromnych kwotach odszkodowań wojennych (tzw. reparacji), którymi w szczególności byli obciążeni Niemcy, co było konsekwencją ich działań podczas I Wojny Światowej. Jak można się domyślać, przedstawiona sytuacja negatywnie odbiła się wśród nastrojów społecznych. Naród niemiecki z powodu zaistniałej sytuacji generalnie był przeciwko „dyktatowi wersalskiemu"9 i przyjętych na nim ustaleń. Pojawiły się hasła obalenia Republiki i chęci odbudowy ustroju monarchicznego ${ }^{10}$. Na dowód sprzeciwu wobec nowego ustroju demokratycznego i przyjętych w Traktacie Wersalskim postanowień, uformowały się liczne organizacje i grupy o poglądach nacjonalistycznych. W gronie liderów i przedstawicieli tych ugrupowań znajdowało się bardzo wielu znanych przedsiębiorców, przemysłowców, a także wojskowych. Wybitny generał piechoty Erich Ludendorff ${ }^{11} \mathrm{w}$ liście do ministra obrony Gustava Noske pisał, iż rząd lekceważy siły zbrojne, a wojsko jest okradane i głodzone przez cywilnych urzędników ${ }^{12}$.

W państwie weimarskim rosło napięcie. Na domiar złego, 10 stycznia 1920 r. weszły w życie postanowienia Traktatu Wersalskiego, a trzy dni później w Berlinie doszło do demonstracji robotniczej na tle ustawy o radach zakładowych ${ }^{13}$. W celu zapobieżenia tej sytuacji, wojsko rozpędziło demonstrujących - zabijając 42 osoby, następnie w dniu 26 stycznia dokonano próby zamachu na jednego z tzw. „zdrajców listopadowych" Matthias'a Erzbergera, który uszedł z życiem, lecz kosztowało go to utratę stanowiska14. Kryzys państwa niemieckiego w okresie republiki weimarskiej powstały, nie tylko przez wystąpienie ruchów o charakterze rewolucyjnym, ale również na skutek wywołania tzw. puczu Kappa - Luttwitza, doprowadził do utworzenia nowego rządu, właśnie z Kappem i Luttwizem na czele. Po przejęciu władzy Kapp wystosował odezwę, w której zadaniem nowej władzy będzie uwolnienie od następstw przegranej wojny i zapewnienie jej uczestnikom prawa do swobodnego rozwoju organizacji wojskowych ${ }^{15}$. Można stwierdzić z perspektywy czasu, iż przeprowadzenie opisywanego zamachu stanu nie było dobrym rozwiązaniem. Wybory, które odbyły się 6 czerwca $1920 \mathrm{r}$. potwierdziły, iż koalicja weimarska przestała być główną siłą polityczną. Jednak przed wyborami związki zawodowe, które miały duży udział $\mathrm{w}$ łagodzeniu zachowań antydemokratycznych - były przekonane, iż zwycięstwo mają praktycznie pewne. Porządek prawnoustrojowy Republiki Weimarskiej niewątpliwie umożliwiał zaprowadzenie stabilizacji i równowagi gospodarczej. Głównymi przesłankami, które można uważać za swego rodzaju mechanizmy hamujące rozwój gospodarczo-handlowy młodej republiki - były nie tylko działania ówczesnych ruchów politycznych, które swoje racje często manifestowały na ulicy, ale

\footnotetext{
${ }^{8}$ J. Krasuski, Historia Rzeszy Niemieckiej 1871-1945, op. cit, s. 288.

${ }^{9}$ T. Kotłowski, Historia Republiki Weimarskiej 1919-1933, op. cit., s. 46.

${ }^{10}$ Ibidem.

${ }^{11}$ R. Parkinson, Tormentedwarrior. Ludendorff and the supreme command, Hodder and Stoughton, London 1978, s. 13-14.

${ }^{12}$ E. Ludendorff, Vom Felderrn zum Weltrevolutionar und Wegbereiter deutscher Yolksschopfung, Munchen 1940, s. 59.

${ }^{13}$ T. Kotłowski, Historia Republiki Weimarskiej, op. cit., s. 48.

${ }^{14}$ H. i E. Hannover, Zanim przyszedł Hitler. Sądy i polityka w Republice Weimarskiej\ Warszawa 1972, s. 153.

${ }^{15}$ T. Kotłowski, Historia Republiki Weimarskiej, op. cit, s. 49.
} 
w większej mierze zobowiązania odszkodowawcze za szkody wyrządzone podczas I Wojny Światowej. Decyzja o nałożeniu kar finansowych miała ogromne znaczenie i konsekwencje dla gospodarki i rozwoju Republiki Weimarskiej.

\section{Plany odbudowy gospodarki: Charlesa Dawesa i Owena Younga/wskazanie problemu reparacji wojennych}

Zastępca głównego inicjatora tzw. planu Dawesa - O. Young na posiedzeniu Komitetu Ekspertów, który od 28 stycznia do 13 lutego odbywał się w Berlinie, spotkał się z przedstawicielami niemieckich polityków, by porozmawiać i przedstawić ocenę niemieckiego budżetu i sytuacji finansowo-podatkowej ${ }^{16}$. Ówczesny kanclerz Niemiec - W. Mara i minister w jego rządzie G. Stresemann, zaakceptowali przestawiony plan.

Kwoty odszkodowawcze, które państwo niemieckie było zobowiązane wpłacić były ogromne - liczone w miliardach marek - według kursu finansowego z tamtego okresu. Należy pamiętać, iż w roku $1923 \mathrm{w}$ Niemczech miało miejsce zjawisko hiperinflacji, czyli gwałtownej podwyżki cen. Zdania ekonomistów są podzielone, jednak w literaturze, przyjmowany jest pogląd, iż utrzymujący się przez kilka-kilkadziesiąt miesięcy nagły wzrost cen o co najmniej $50 \%$, jest uznawany za umowną granicę hiperinflacji ${ }^{17}$. W Niemczech zjawisko to, miało miejsce w roku 1923, kurs marki niemieckiej wynosił - w styczniu 10000 marek za dolara, w lutym 50000, żeby w listopadzie osiągnąć historyczne przeliczenie walutowe, bo aż 4,2 biliona za jednego dolara amerykańskiego ${ }^{18}$.

Plan gospodarczy Dawesa, przewidywał, że źródłami pokrycia strat będą przede wszystkim: dochody państwa (1,5 mld rocznie), emisja zabezpieczonych hipotetycznie obligacji kolei Rzeszy, obligacje przemysłowe, jak również pożyczka zagraniczna. W ramach egzekwowania postanowień opisywanego planu zmodyfikowano skład Reichsbanku. W jego radzie nadzorczej znaleźli się przedstawiciele państw zachodnich, a kontrolę niemieckiej gospodarki miał sprawować Generalny Agent Reparacyjny ( Parker S. Gilbert) ${ }^{19}$.

W ocenie Komisji Odszkodowań Wojennych zachodziły rażące różnice pomiędzy wyliczeniami rządu niemieckiego w sprawie spłat należnych kwot odszkodowawczych, a stanem faktycznym. Do momentu wejścia planu Dawesa, większą część należnego zadłużenia za spowodowanie zniszczeń stanowiły świadczenia w naturze. Rząd niemiecki twierdził, iż zapłacił równowartość 40689 milionów złotych marek, natomiast zdaniem Komisji, ta kwota wynosiła zaledwie 8719 milionów20.

Ogólna kwota, którą Niemcy uiścili z tytułu odszkodowań wojennych, faktycznie wynosiła ${ }^{21}$ :

\begin{tabular}{|l|l|l|}
\hline & $\begin{array}{l}\text { Ocena rządu } \\
\text { niemieckiego }\end{array}$ & $\begin{array}{l}\text { Ocena Komisji } \\
\text { Odszkodowań }\end{array}$ \\
\hline
\end{tabular}

\footnotetext{
${ }^{16}$ T. Kotłowski, Historia Republiki Weimarskiej 1919-1933, op. cit., s. 146.

${ }_{17}^{17}$ C. Ragan, R. Lipsey, Macroeconomics, Pearson Education Canada, Toronto 2008, s. 645.

${ }^{18}$ Wł. Czapliński, A. Galos, W. Korta, Historia Niemiec, Zakład Narodowy im. Ossolińskich 1981, s. 696 i 697.

${ }^{19}$ H. Winkler, Weimar 1918-1933 Die Geschichte der ersten Deutschen Demokratie Broschierte Sonderausgabe, Verlag, C.H. Beck 2005, s. 244 i n.

${ }^{20}$ J. Krasuski, Historia Rzeszy Niemieckiej 1871-1945, op. cit, s. 277.

${ }^{21}$ B. Gebhardt, Handbuch der deutschen Geschichte, t. 4, Stuttgart 1959, s. 358.
} 


\begin{tabular}{|l|l|l|}
\hline Do chwili wejścia w życie planu Dawesa & 40689 & 8719 \\
\hline $\begin{array}{l}\text { Świadczenia wymuszone w czasie okupacji } \\
\text { Zagłębia Ruhry przez Belgię i Francję w }\end{array}$ & 1370 & 921 \\
\hline Świadczenia na podstawie Planu Dawesa & 7993 & 7553 \\
\hline Świadczenia na podstawie Planu Younga & 3103 & 2800 \\
\hline Razem & marek & złotych marek \\
\hline
\end{tabular}

Źródło : B. Gebhardt, Handbuch der deutschen Geschichte, t. 4, [w ]: J. Krasuski, Historia Rzeszy Niemieckiej 18711945, s. 278.

Niemcy zgodnie z przedstawionym zestawieniem, nie zapłaciły nawet połowy wymaganej kwoty. Komisja Odszkodowań wojennych w 1923 r. wyliczyła, iż łączna suma zadłużenia tytułem odszkodowania za zniszczenia wojenne wynosiła 132 miliarda marek ${ }^{22}$. Podana kwota miała być podzielona pomiędzy państwami zwycięskimi, zgodnie z ustaleniami układu zawartego przez W. Brytanię, Japonię, Portugalię i Włochy w Spa, 16 lipca 1920 r. ${ }^{23}$.

Gospodarka niemiecka była pod międzynarodową kontrolą, raty kwoty odszkodowania spłacano regularnie, zagraniczne przedsiębiorstwa chętnie inwestowały - te wszystkie czynniki pozwoliły gospodarce niemieckiej powoli podnosić się z głębokiego kryzysu gospodarczego, spowodowanego m.in. przez działania wojenne na frontach I wojny światowej oraz zjawiskiem hiperinflacji na niespotykaną dotąd skalę. Szacuje się, iż do końca 1930 r. do gospodarki niemieckiej napłynęło - włącznie z inwestorami zagranicznymi i pomocą finansową od innych państw prawie 16,3 mld. dolarów ${ }^{24}$.

Plan Dawesa został ratyfikowany 29 sierpnia 1924 r, jednak miał on bardzo krótką rację bytu - zaledwie pięcioletnią. Niemcy zarzucali państwom kontrolującym, iż ich gospodarka jest nadmiernie kontrolowana, a to jest przyczyną spadku jej pozycji międzynarodowej i ich siły w Europie. Zgodnie z przedstawionym stanem faktycznym, przeprowadzono nowe rokowania w sprawie modyfikacji ustaleń zawartych w przyjętym planie Dawesa - stało się to w roku 1928 z inicjatywy ówczesnego Kanclerza Niemiec Hermana Miillera25.

\footnotetext{
22 J. Krasuski, Historia Rzeszy Niemieckiej 1871-1945, op. cit., s. 278.

${ }^{23}$ Ibidem.

${ }^{24}$ A. Czubiński, J. Strzelczyk, Zarys dziejów Niemiec i państw powstałych po II Wojnie Światowej, wyd. I, Wydawnictwo Poznańskie, Poznań 1986 r., s. 307.

${ }^{25}$ T. Kotłowski, Historia Republiki Weimarskiej 1919-1933 op. cit, s. 150.
} 
Po przeprowadzeniu analizy stanu gospodarki Republiki Weimarskiej przez rzeczoznawców i ekonomistów zachodnich, po czterech miesiącach został uzgodniony tzw. plan Younga, który był nowym planem gospodarczym państwa niemieckiego ${ }^{26} .20$ stycznia 1930 roku w Hadze podpisano układ wprowadzający plan Younga.

Został on przyjęty, głównie w szeregach opozycji prawicowej. Przewidywał on niższe raty, jednak miały być spłacane aż do roku 1988, co powodowało poważne skutki psychologiczne wśród społeczeństwa ${ }^{27}$. Kwota zadłużenia była astronomiczna - 132 miliardy złotych marek, nadto dochodziły jeszcze do tego zobowiązania wobec Stanów Zjednoczonych, które zaciągnięto na potrzeby spłaty odszkodowań28. Podobnie jak poprzednio przyjęty gospodarczy plan Dawesa, nie przetrwał długo. Na domiar złego został on podpisany w czasie jednego z największych kryzysów ekonomicznych w historii, taki splot okoliczności nie mógł pozwolić na powodzenie i odbudowę gospodarzą wraz ze spłatą roszczeń odszkodowawczych. Alfred Hugenberg i A. Hitler zorganizowali ogólnonarodowe referendum przeciwko przyjętemu planowi gospodarczemu Younga, zostało one przegrane, jednak był to pokaz siły opozycji i przeciwników ówczesnego rządu.

\section{Geneza i problem reparacji wojennych}

Mimo przyjęcia nowej strategii gospodarczej, trudności płatnicze spowodowane przez światowy kryzys gospodarczy, zmusiły władze państwa niemieckiego do wystąpienia z prośbą do rządu amerykańskiego o odroczenie spłat zadłużenia. Herbert Hoover, w tamtym okresie pełniący funkcję Prezydenta Stanów Zjednoczonych, ogłosił w dniu 20 czerwca 1931 r. roczne moratorium w sprawie spłat odszkodowań niemieckich, jak i długów państw zachodnich ${ }^{29}$.

Szkody materialne, które poniosła Europa w czasie walk na frontach I wojny światowej były niebagatelnie wysokie. W dużej mierze odpowiedzialność za ich wyrządzenie spoczywała na państwie niemieckim. Sankcją, którą obarczono Niemcy za wszystkie dokonane zniszczenia były tzw. reparacje wojenne, innymi słowy wypłata stosownych odszkodowań państwom dotkniętym zbrojnymi działaniami Niemiec.

Międzynarodowa Komisja Odszkodowań w dniu 30 listopada 1923 r. powołała do życia Komitet Ekspertów z siedzibą w Londynie. Na czele tej organizacji stanął Ch. G. Dawers, który za cel miał przyjąć wypracowanie generalnej koncepcji rozwiązania kwestii niemieckiej Przedmiotowy program w dużej mierze miał się opierać na trzech głównych elementach:

-jedność gospodarcza Niemiec;

-zdolność produkcyjna;

-zakończenie kontroli francuskiej nad Zagłębiem Ruhry.

Po analizie sytuacji gospodarczej i politycznej w Niemczech, Komitet Ekspertów ogłosił, iż państwo niemieckie zobowiązane jest opłacać roczny limit spłat reparacji. Co roku kwota limitu stopniowo wzrastała, nadto Niemcy w ciągu 5 lat byli zobowiązani do wypłaty 7170 tys. marek w złocie ${ }^{30}$ i rzeczywiście zobowiązanie te, jako jedne z nielicznych zostało dochowane.

Plan odbudowy gospodarki niemieckiej, który był nazywany od imienia przewodniczącego Komitetu Ekspertów - planem Dawesa, przewidywał zasady spłat i regulacji

\footnotetext{
${ }^{26}$ J. Curtius, Der Young-Plan. Entstehung und Wahrheti, Stuttgart 1950, s. 116-118

${ }^{27}$ J. Curtius, Der Young-Plan. Entstehung und Wahrheti, Stuttgart 1950, s. 116-118.

${ }^{28}$ Ibidem.

${ }^{29}$ J. Kiwierska, Między izolacjonizmem a zaangażowaniem : Europa w polityce Stanów Zjednoczonych od Wilsona do Roosevelta, wyd. I, Instytut Zachodni, Poznań 1995, s. 294-296.

${ }^{30}$ Cz. Łuczak, Dzieje gospodarcze Niemiec 1871-1990, Wydawnictwo Naukowe UAM, Poznań 2012, s. 147.
} 
zobowiązań. W swojej treści miał również m.in. zniesienie świadczeń rzeczowych, emisję zabezpieczonych, a także zniesienie wszelkich świadczeń rzeczowych.

Wkrótce problem reparacji wojennych państwa niemieckiego rozwiązał się całkowicie. Sytuacja ekonomiczna i pogłębiony kryzys gospodarczy w Niemczech, w roku 1931 definitywnie zakończył temat spłat odszkodowań wojennych. Układ w Lozannie, który został zawarty 9 lipca 1932 r. rozwiązywał problem reparacji (brak realizacji programu Younga, nawet po upływie terminu wskazanego przez Hoovera). Niemcy, podpisując porozumienie z Lozanny, byli zobowiązani w ciągu 3 lat zapłacić - 3 mld mk. w złocie, płatność, co ciekawe mogła być również dokonywana obligacjami, które nie zostały sprzedane w ciągu 15 lat od daty ich wydania ${ }^{31}$. W przypadku braku zupełnej możliwość wpłat - zobowiązanie mogło być umorzone, wskazuje to, iż moratorium z Lozanny faktycznie kończyło finansową odpowiedzialność Niemców za straty i zniszczenia dokonane w czasie I Wojny Światowej.

Zawiłą sytuację związaną z reparacjami wojennymi ostatecznie zakończył A. Hitler, który po dojściu do władzy ogłosił, iż jakiekolwiek roszczenia z tytułu odszkodowania za działania państwa niemieckiego podczas wojny, nie będą w przyszłości wypłacane.

\section{Sytuacja gospodarcza Rzeszy Niemieckiej w latach 1924-1929}

Sytuacja gospodarcza Republiki Weimarskiej w latach 1924-1929 uległa znacznej poprawie, było to przyczyną m.in. dużych inwestycji kapitału zagranicznego. Napływ nowych inwestorów ułatwił i przyspieszył proces rozwoju przemysłu niemieckiego, handlu oraz pomógł w modernizowaniu przedsiębiorstw i ekspansji gospodarczej. Nakłady kapitału zagranicznego w latach 1924-1929 wyniosły 19 mld. złotych marek ${ }^{32}$.

Umożliwiło to zwiększenie stopnia mechanizacji pracy, co zmniejszyło koszty zatrudnienia, oraz pozwoliło na unowocześnienie gospodarcze przedsiębiorstw niemieckich. Rozmiar produkcji poszczególnych surowców uległ znacznemu wzrostowi ${ }^{33}$ :

-węgiel kamienny z 119 do $163 \mathrm{mln}$ ton;

-rudy żelaza z 4,5 do 6,4 mln ton;

-energia elektryczna z 18,7 do $28 \mathrm{mln} \mathrm{kW}$.

W Niemczech szybko rozwijał się przemysł samochodowy (w 1929 r. wyprodukowano 238 tys. samochodów osobowych), wzrosła liczba zarejestrowanych patentów, odbudowano flotę morską, a także wzrostowi uległ dochód narodowy - państwo niemieckie wytworzyły 150\% dochodu z 1913 r. (ok. 75 bln marek) ${ }^{34}$. W produkcji przemysłowej Republika Weimarska prześcignęła Wielką Brytanię, która od zawsze była największym rywalem w większości dziedzin życia społecznego, a szczególnie, jeżeli chodzi o aspekt gospodarczy. W Europie Środkowej i Wschodniej firmy niemieckie (takie jak: IG Farben, Zjednoczone Stalownie Rheinelbe Union, Zakłady Thyssena, Phenix i Rheinische Stahlwerke, Deimler-Benz, Auto-Union) przodowały w przemyśle - samochodowym, chemicznym, metalowym, ustanawiając niekiedy monopol (np. Zjednoczone Stalownie, których kapitał zakładowy wynosił $800 \mathrm{mln}$ marek, a liczba osób zatrudnionych wynosiła prawie 160 tys.) ${ }^{35}$. Co ciekawe, w przemyśle chemicznym wspomniany gigant IG Farben (Interessen-Gemeinschaft Farbenindustrie), którego kapitał wynosił 1,1 mld marek i zatrudniał prawie 98 tysięcy osób (razem pracownicy oraz urzędnicy)

\footnotetext{
${ }^{31}$ IM. Baumgart, Londyn - Berlin 1918-1939, Polskie Tow. Historyczne oddział w Szczecinie 1993, s. 143-150.

${ }^{32}$ T. Kotłowski, Historia Republiki Weimarskiej 1919-1933, op. cit., s. 153.

${ }^{33}$ Cz. Łuczak, Dzieje gospodarcze Niemiec 1871-1990, op. cit., s. 99-101.

${ }^{34}$ T. Kotłowski, Historia Republiki Weimarskiej 1919-1929, op. cit., s. 154 i 155.

${ }^{35}$ Ibidem 155.
} 
miał $35 \%$ udziałów w całej niemieckiej produkcji ${ }^{36}$. W przemyśle samochodowym przodował Demiler-Benz i Auto-Union; w elektrotechnicznym Siemens-Halske - kontrolowały ok. 4/5 produkcji tych gałęzi gospodarki ${ }^{37}$.

Można stwierdzić, iż Rzesza Niemiecka - pod względem gospodarczym - ponownie dominowała w Europie Środkowej38. Szczególną dynamiką cechował się niemiecki eksport, Republika Weimarska znalazła się na drugim miejscu, zaraz po Stanach Zjednoczonych -krajów eksportujących największą ilość produktów.

Rozwój powyżej opisanych dziedzin i gałęzi gospodarki, należy zawdzięczać, przede wszystkim inwestycjom i napływu kapitału zagranicznego, pożyczek bankowych, oraz zadłużeń państwowych. Wszystkie te czynniki, pozwoliły na stabilizację gospodarczą i ekonomiczną w Niemczech.

Jednakże, sytuacja $\mathrm{w}$ rolnictwie nie wyglądała tak dobrze, jak to miało miejsce we wcześniej wskazanych sferach gospodarczych. Taki stan rzeczy, był skutkiem niedoinwestowania, trudną rentownością, a także problemami strukturalnymi. $\mathrm{W}$ rolnictwie był widoczny proces rozdrobnienia, brakowało modernizacji, unowocześnienia oraz mechanizacji gospodarstw rolnych ${ }^{39}$. Pomimo tego, sytuacja gospodarcza Republiki Weimarskiej była dosyć stabilna.

Należy stwierdzić, iż lata 1924-1929 były pod względem rozwoju gospodarczego i ekonomicznego dla państwa niemieckiego przełomem. Nastąpiła, m.in. poprawa warunków bytowych, wzrósł dochód narodowy na jednego mieszkańca, zwiększono liczbę miejsc pracy, powstały liczne oddziały przedsiębiorstw zagranicznych, patrząc na burzliwą sytuację polityczno-gospodarczą Rzeszy Niemieckiej (manifestacje, przewroty, strajki, reparacje wojenne, nadzór gospodarczy państw zachodnich) wydawało by się, iż jest to niemożliwe.

Uważam, iż głównymi czynnikami ustabilizowania i rozwoju gospodarczego Niemiec były niewątpliwie - przypływ kapitału zagranicznego, oraz zawarcie traktatu w Lozannie -bez takiego biegu zdarzeń Republika Weimarska nie mogła by powrócić do czołówki krajów wysoko uprzemysłowionych $^{40}$ i ponownie dominować pod względem gospodarczym w Europie Środkowej ${ }^{41}$.

\section{Podsumowanie i próba oceny polityki gospodarczej Niemiec ( 1924-1929)}

Historia polityczna i gospodarcza Republiki Niemiec w okresie 1924-1929, przedstawia się bardzo zróżnicowanie. Od bardzo trudnych początków kiedy rozwój państwa niemieckiego był blokowany przez liczne ruchy i wystąpienia narodowe, następnie miało miejsce spowolnienie rozwoju gospodarczego, spowodowane przez nałożenie oraz zobowiązanie do płacenia reparacji wojennych i wreszcie okres stabilizacji oraz umocnienia gospodarczego. Na tak burzliwą sytuację gospodarczo-polityczną Rzeszy Niemieckiej wpływ miało wiele czynników. Przede wszystkim upadek i kryzys gospodarczy w początkowych latach Republiki, był następstwem hiperinflacji. Zjawisko te, spowodowało, m.in. zadłużenie u państw zachodnich,

\footnotetext{
${ }^{36}$ H.Tammen, Die I.G. Farben Aktiengesellschaft (1925-1933). Ein Chemiekonzern in der Weimarer Republik, Berlin 1978, s. 31-36, 124-131.

${ }^{37}$ R.Liefmann, Kartelle, Konzerne und Trusts, Stuttgart 1930, s.181-202.

${ }^{38}$ J. Koszel, Rywalizacja, niemiecko-włoska w Europie Środkowej i na Bałkanach w latach 1933-1939, Poznań 1987 , s. 59 i n.

${ }^{39}$ T. Kotłowski, Historia Republiki Weimarskiej 1919-1929, op. cit., s. 158-159.

${ }^{40}$ Ibidem, s. 149.

${ }^{41}$ I. Geiss, B. J. Wendt, Deutschland in der Weltpolitik des 19. und 20. Jahrhunderts, Diisseldorf 1973, s. 483512 .
} 
wzrost bezrobocia, kryzysem walutowym, a w konsekwencji złymi nastrojami społecznymi, których skutkiem były liczne próby przewrotu i brak zaufania do ustroju demokratycznego.

Dopiero umorzenie odszkodowań wojennych przez państwa zachodnie, po podpisaniu porozumienia w Lozannie dało początek stabilizacji gospodarczej. Rozwój ekonomiczny państwa niemieckiego następował niezwykle szybko. Poprawa była widoczna we wszystkich sferach gospodarczych. Inwestorzy zagraniczni, chętnie inwestowali swój kapitał, co pozwoliło stworzyć większą ilość miejsc pracy.

Przedsiębiorstwa niemieckie (przemysł samochodowy, chemiczny, metalowy), były największymi potentatami w Europie Środkowej i Wschodniej. Nagły wzrost koniunktury powodował, iż mieszkańcy Niemiec powoli wracali do normalnej egzystencji gospodarczej, tej, która miała miejsce jeszcze przed I wojną światową.

Niestety, po dojściu do władzy A. Hitlera i jego partii NSDAP sytuacja ekonomiczna Republiki Weimarskiej kompletnie się zmieniła. Nie istniało pojęcie wolności gospodarczej, własności, czy nawet swobody przepływu kapitału.

Budowanie mechanizmów i podstaw polityki gospodarczej, które w okresie kilkudziesięciu lat od zakończenia wojny (1914-1918 r.) niewątpliwie uległy zachwianiu, zostało w parę miesięcy zniszczone.

\section{Bibliografia:}

\section{Wydawnictwa zwarte:}

Baumgart M, Londyn - Berlin 1918-1939, Polskie Tow. Historyczne oddział w Szczecinie 1993.

Curtius J., Der Young-Plan. Entstehung und Wahrheit, Stuttgart 1950.

Czapliński Wł., A. Galos, W. Korta, Historia Niemiec, Zakład Narodowy im. Ossolińskich 1981.

Czubiński A, Strzelczyk J., Zarys dziejów Niemiec i państw powstałych po II Wojnie Światowej, wyd. I, Wydawnictwo Poznańskie, Poznań 1986 r.

Die Yerfassung der Weimarer Republik vom 11. August 1919, Stuttgart 2009.

Gebhardt B., Handbuch der deutschen Geschichte, Tom 4, Sttutgart 1959.

Geiss I., Wendt B. J., Deutschland in der Weltpolitik des 19. und 20. Jahrhunderts, Dusseldorf 1973.

Hannover H. i E., Zanim przyszedł Hitler. Sądy i polityka w Republice Weimarskiej, Warszawa 1972.

Kiwierska J., Między izolacjonizmem a zaangażowaniem: Europa w polityce Stanów Zjednoczonych od Wilsona do Roosevelta, wyd. I, Instytut Zachodni, Poznań 1995.

Koszel J., Rywalizacja, niemiecko-włoska w Europie Środkowej i na Bałkanach w latach 19331939, Poznań 1987.

Kotłowski T., Historia Republiki Weimarskiej 1919- 1933, Instytut Historii UAM, Poznań 1997.

Krasuski J., Historia Rzeszy Niemieckiej 1871-1945, Wydawnictwo Poznańskie 1969.

Liefmann R., Kartelle, Konzerne und Trusts, Stuttgart 1930.

Ludendorff E., Vom Felderrn zum Weltrevolutionar und Wegbereiter deutsche Yolksschopfung, Munchen 1940.

Łuczak Cz.,

Dzieje gospodarcze Niemiec 1871-1990, Wydawnictwo Naukowe UAM, Poznań 2012.

Parkinson R., Tormented warrior. Ludendorff and the supreme command, Hodder and Stoughton, London 1978.

Ragan C., R. Lipsey, Macroeconomics, Pearson Education Canada, Toronto 2008.

Tammen H., Die I.G. Farben Aktiengesellschaft (1925-1933). Ein Chemiekonzern In der Weimarer Republik, Berlin 1978.

Winkl H., Weimar 1918-1933 Die Geschichte der ersten Deutschen Demokratie Broschierte Sonderausgabe, Yerlag, C.H. Beck 2005. 


\section{Źródła historyczne:}

l.Die Yerfassung der Weimarer Republik vom 11. August 1919, Stuttgart 2009. 